\title{
IMPLEMENTASI METODE BERMAIN PERAN UNTUK PENINGKATAN KEMAMPUAN MENYIMAK ANAK USIA DINI DI PAUD SEKARWANGI DESA BANGOREJO BANYUWANGI 2017
}

\author{
Luh Putu Indah Budyawati ${ }^{1}$, Wiwin Hartanto ${ }^{2}$ \\ ${ }^{1}$ Program Studi Pendidikan Anak Usia Dini, Fakultas Keguruan dan Ilmu Pendidikan, Universitas Jember \\ e-mail: indahbudyawati.fkip@unej.ac.id \\ ${ }^{2}$ Program Studi Pendidikan Ekonomi, Fakultas Keguruan dan Ilmu Pendidikan, Universitas Jember \\ e-mail: wiwinhartanto@unej.ac.id
}

\begin{abstract}
Abstrak
Penelitian ini secara umum bertujuan memberi pemecahan masalah pada kemampuan menyimak anak kelompok A di PAUD Sekarwangi Desa Bangorejo Banyuwangi. Selain itu secara khusus penelitian ini akan membahas tentang peningkatan kemampuan menyimak anak yang dikembangkan menggunakan metode bermain peran. Metode penelitian yang digunakan berupa Penelitian Tindakan (Action Research) yang dilakukan dalam bentuk siklus tindakan. Penelitian ini secara teoritik memiliki manfaat dalam pengembangan kemampuan menyimak anak sedangkan secara aplikatif hasil penelitian ini bisa dimanfaatkan dalam pendidikan anak khususnya stimulasi kemampuan menyimak yang dikembangkan melalui metode bermain peran. Keberhasilan desiminasi hasil penelitian ini pada masyarakat luas akan menguatkan keilmuan pendidikan anak usia dini yang dikembangkan pada lingkup universitas, sehingga perguruan tinggi akan menjadi pusat penemuan solusi dari permasalahan yang ada di masyarakat.
\end{abstract}

Kata Kunci: metode bermain peran, kemampuan menyimak AUD

\section{PENDAHULUAN}

Masa kanak-kanak atau usia dini merupakan masa keemasan (the golden age) yang juga berarti sebagai masa sensitif (the period of sensitivity) anak untuk mendapatkan berbagai pengalaman dalam pertumbuhan dan perkembangannya. Pada masa ini otak anak juga sedang tumbuh dan berkembang sejalan dengan rang sangan atau stimulus yang diterima dari lingkungannya. Apabila anak mendapatkan stimulasi yang benar, maka secara efektif dan efisien segala informasi akan mudah diserap oleh anak. Agar potensi yang dimiliki anak tetap terjaga dan dapat dioptimalkan perkembangannya maka diberikan dengan cara atau metode yang menarik. Dengan metode menarik yang diberikan untuk anak, terdapat salah satu aspek yang dapat dikembangkan oleh anak yaitu kemampuan berbahasa. Bahasa menjadi faktor penting dalam proses ini karena saat bermain bersama teman, terdapat kemungkinan bagi anak untuk berkomunikasi dengan cara memberikan pendapat dan saling bertanya satu sama lain. Dalam teori perkembangan bahasa yang ditemukan oleh para ahli, ketika anak mampu melakukan tugas-tugas bahasa yang kompleks pada usia dini maka makin mempermudah anak tersebut dalam menguasai makna dan tata bahasa (2003:328).

Fenomena ketimpangan komunikasi ini muncul terlebih ketika anak baru mulai masuk lembaga pendidikan anak usia dini sedangkan disisi lain anak masih memiliki cara berkomunikasi di keluarga yang sangat beragam. Masalah lain yang muncul dari fenomena tersebut yaitu ketika guru memberikan instruksi dalam bahasa Indonesia, kebanyakan anak-anak belum dapat menyimak pesan yang disampaikan oleh guru sehingga guru harus mengulang kembali pesan yang telah disampaikan sebelumnya kepada anak. Kemampuan menyimak anak-anak belum terlihat begitu baik, hal ini terlihat dari seringnya seorang guru menyampaikan pesan yang sama dalam beberapa saat kepada anak-anak terlebih lagi kepada anak-anak yang berusia 4-5 tahun dimana mereka merupakan murid baru dalam TK tersebut. Permasalahan ini terjadi pada anak-anak di kelompok A di PAUD Sekarwangi Desa 
Bangorejo Banyuwangi.

Kemampuan menyimak pada usia dini merupakan hal yang penting karena melalui menyimak inilah anak akan mulai belajar menguasai bahasa. Dengan memiliki kemampuan menyimak yang baik maka anak akan dengan mudah mengerjakan atau melaksanakan instruksi atau pesan yang didengar atau disampaikan kepadanya. Sehingga dapat kita mengerti bahwa metode yang akan kita terapkan bagi anak usia dini sangat perlu diperhatikan dan dipilih yang baik serta menarik agar anak bisa memiliki kemampuan menyimak yang baik. Peningkatan kemampuan berbahasa Indonesia ini dilakukan dengan menggunakan metode yang menarik bagi anak agar anak dapat menyimak dengan baik apa yang disampaikan oleh guru.

Salah satu cara yang menarik dilakukan dalam mengembangkan kemampuan menyimak pada anak yaitu metode bermain peran. Aktifitas bermain peran yang sudah dirancang dengan struktur bahasa Indonesia sehingga mampu meningkatkan kemampuan anak dalam berbahasa Indonesia terutama dalam menyimak. Tiap kalimat yang didengar oleh anak dapat melatih anak dalam menyimak percakapan yang didengar sehingga anak-anak menjadi terbiasa mendengarkan kalimat dan ungkapan dalam bahasa Indonesia sekalipun mereka mungkin pernah mendengar kalimat dan ungkapan tersebut di tempat lain sebelumnya. Melalui sebuah penelitian di harapkan dapat menjawab beberapa permasalahan yang kerap dihadapi di masyarakat maupun di lembaga anak usia dini didaerah dengan kegiatan pembelajaran atau stimulasi berbahasa bagi anak usia dini terutama dalam meningkatkan kemampuan menyimak anak usia dini.

Berdasarkan latar belakang masalah yang telah dikemukakan sebelumnya maka teridentifikasi rumusan masalah yang akan diamati dan diberikan penanganan melalui penelitian ini, yaitu "Bagaimanakah implementasi metode bermain peran untuk meningkatkan kemampuan menyimak pada anak kelompok A di PAUD Sekarwangi Desa Bangorejo Banyuwangi?"

Adapun tujuan dari penelitian ini adalah untuk mengetahui bagaimana implementasi metode bermain peran untuk meningkatkan kemampuan menyimak pada anak kelompok A di PAUD Sekarwangi Desa Bangorejo Banyuwangi.

Adapun manfaat yang diharapkan dari penelitian ini adalah sebagai berikut. (1) Manfaat Teoritis, Hasil penelitian ini diharapkan dapat memberikan suatu informasi tentang peningkatan kemampuan menyimak anak melalui metode bermain peran. (2) Manfaat Praktis; a) Bagi Anak, Dengan mengimplementasikan metode bermain peran, anak mendapat pengalaman belajar yang menyenangkan sehingga anak mampu meningkatkan kemampuan menyimak. Selanjutnya, anak mampu menyiapkan diri untuk jenjang pendidikan dasar. b) Bagi Guru, Penelitian ini dapat digunakan sebagai salah satu alternatif dalam mengatasi metode pembelajaran tepat yang menjadi kendala utama dalam kegiatan pembelajaran. Dengan menggunakan metode bermain peran ini, guru dapat membelajarkan anak menjadi lebih bermakna, dan mengoptimalkan kemampuan menyimak anak. c) Bagi Sekolah; Penelitian ini dapat dijadikan bahan pertimbangan dalam pengembangan kemampuan menyimak anak dan diharapkan dapat dikembangkan dalam bidang kemampuan yang lainnya. d) Bagi Peneliti; Penelitian ini dapat memberikan pengalaman langsung kepada peneliti sebagai tenaga pendidik dalam menerapkan metode bermain peran.

Luaran yang diharapkan dari penelitian ini adalah rancangan sederhana berupa program kegiatan seperti RKH, dan materi ajar serta artikel ilmiah yang siap dipublikasikan di jurnal nasional. Luaran lainnya, yaitu dengan penerapan metode bermain peran diharapkan mampu mengembangkan kemampuan menyimak secara optimal.

\section{METODE}

Penelitian ini tergolong penelitian tindakan kelas (action research). Penelitian ini 
menggambarkan bagaimana suatu pembelajaran diterapkan dan bagaimana hasil yang ingin dicapai dapat dicapai. Objek penelitian ini, yaitu: 1) metode bermain peran, 2) kemampuan menyimak, dan 3) respon anak. Subjek penelitian ini berjumlah 16 orang yang terdiri dari 6 laki-laki dan 10 wanita.

Penelitian tindakan kelas ini dilaksanakan mengikuti pola Kemmis dan Taggart (1988), yaitu berbentuk spiral dan siklus yang satu ke siklus berikutnya. Setiap siklus terdiri dari empat tahapan yaitu: (1) perencanaan, (2) tindakan, (3) observasi/evaluasi, dan (4) refleksi. Adapun desainnya tersaji seperti Gambar 0.1.

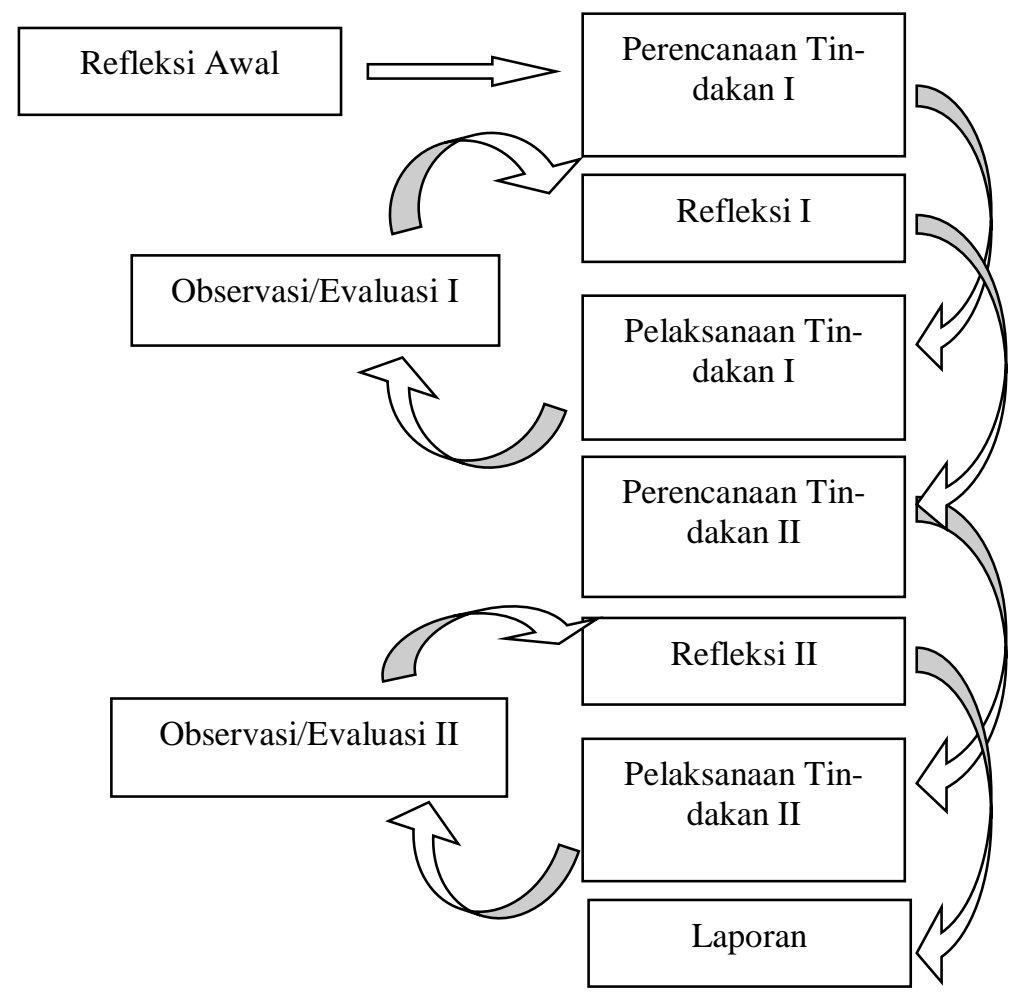

\section{Skema Desain Penelitian Tindakan Kelas}

(Diadaptasi dari Kemmis dan Taggart dalam Suarsana, 2010)

Terdapat dua macam data dalam penelitian ini, yaitu data pemantau tindakan (action) dan data penelitian (research). Data ini digunakan untuk keperluan analisis data penelitian sehingga diperoleh gambaran peningkatan kemampuan klasifikasi anak.

Teknik yang digunakan dalam menjaring data tentang pemantauan tindakan adalah dengan menggunakan lembar pengamatan/observasi (non tes), yakni berdasarkan keterlibatan peneliti dalam penelitian ini adalah observasi partisipan. Pengamatan dilakukan secara langsung dengan dibantu menggunakan kamera sebagai bukti dokumentasi kegiatan. Teknik pengumpulan data yang digunakan untuk menjaring data penelitian (research) adalah non tes, yakni dengan menggunakan daftar checklist. Dalam pengisian lembar observasi, pengamat memberikan tanda check list $(\sqrt{ })$ pada skala kemunculan kemampuan klasifikasi anak yang sesuai.

Instrumen yang digunakan pada penelitian ini berupa instrumen perlakuan, instrumen pemantau tindakan, dan instrumen pengumpul data penelitian. Instrumen perlakuan yang diberikan kepada anak berupa kegiatan dengan metode bermain peran. Instrumen yang digunakan untuk 
pemantauan tindakan yang dilakukan pada penelitian, yaitu berupa lembar observasi dan wawancara. Instrumen yang digunakan untuk mengumpulkan data penelitian berupa daftar checklist yang menunjukkan indikator kemampuan klasifikasi anak. Jenis instrumen dan teknik pengumpulan data terlihat pada Tabel 0.2 .

Table 0.2.

Jenis Instrumen dan Teknik Pengumpulan Data

\begin{tabular}{|c|l|c|c|l|c|}
\hline No. & Jenis Data & $\begin{array}{c}\text { Teknik } \\
\text { Pengumpulan } \\
\text { data }\end{array}$ & Instrumen & Pelaksanaan & $\begin{array}{c}\text { Teknik } \\
\text { Analisis } \\
\text { Data }\end{array}$ \\
\hline 1 & $\begin{array}{l}\text { Kemampuan } \\
\text { Klasifikasi }\end{array}$ & Observasi & $\begin{array}{c}\text { Lembar Observasi } \\
\text { dan ceklis }\end{array}$ & Proses & $\begin{array}{l}\text { Statistik } \\
\text { deskriptif }\end{array}$ \\
\hline 2 & $\begin{array}{l}\text { Respons } \\
\text { anak }\end{array}$ & $\begin{array}{c}\text { Observasi dan } \\
\text { Wawancara }\end{array}$ & $\begin{array}{c}\text { Lembar Observasi } \\
\text { dan wawancara }\end{array}$ & $\begin{array}{l}\text { Proses dan } \\
\text { Akhir }\end{array}$ & $\begin{array}{l}\text { Statistif } \\
\text { deskriptif }\end{array}$ \\
\hline
\end{tabular}

Respons anak dikumpulkan dengan menggunakan Lembar observasi dan respon anak. Dalam Lembar observasi tersebut terdapat pernyataan dengan masing-masing 5 pilihan yaitu sangat setuju/sangat senang (SS), setuju/senang (S), ragu-ragu/biasa saja (R), tidak setuju/tidak senang (TS), sangat tidak setuju/sangat tidak senang (STS). Pemberian skor pada setiap item $S S=5, S=4, R=3, T S=2$, $\mathrm{STS}=1$ untuk pernyataan menyenangkan. Untuk pernyataan negatif diberi skor $\mathrm{SS}=1, \mathrm{~S}=2, \mathrm{R}=3$, TS=4, $\mathrm{STS}=5$.

Pada penelitian ini menggunakan teknik analisis statistik deskriptif, yaitu menggambarkan kenyataan atau fakta sesuai dengan data yang diperoleh dengan tujuan untuk mengetahui prestasi belajar yang dicapai anak juga untuk memperoleh tanggapan anak terhadap kegiatan bermain pembelajaran. Analisis ini dihitung dengan menggunakan statistik deskriptif. Untuk mengukur kemampuan klasifikasi anak peneliti melakukan penjumlahan skor yang diperoleh anak, yang selanjut-nya dibagi dengan jumlah anak yang ada di kelas tersebut sehingga diperoleh rata-rata skor kemampuan klasifikasi anak.

Ketuntasan belajar anak dalam penelitian ini dikatakan berhasil jika mencapai ketuntasan belajar sebanyak $\geq 80 \%$. Persentase ketuntasan belajar ditentukan berdasarkan kesepakatan antara peneliti dengan guru yang bersangkutan. Untuk memenuhi kriteria tersebut maka skor data yang diperoleh harus dikonversi ke skala 100. Penggolongan respons anak, ditetapkan berdasarkan lima jenjang kategori seperti pada Tabel 0.3

Tabel 0.3

Kriteria Penggolongan Respon Anak

\begin{tabular}{|c|c|c|}
\hline No & Kriteria & Kategori \\
\hline 1 & $\bar{x} \geq \mathrm{MI}+1,5 \mathrm{SDI}$ & Sangat positif \\
\hline 2 & $\mathrm{MI}+0,5 \mathrm{SDI} \leq \bar{x}<\mathrm{MI}+1,5 \mathrm{SDI}$ & Positif \\
\hline 3 & $\mathrm{MI}-0,5 \mathrm{SDI} \leq \bar{x}<\mathrm{MI}+0,5 \mathrm{SDI}$ & Cukup positif \\
\hline 4 & $\mathrm{MI}-1,5 \mathrm{SDI} \leq \bar{x}<\mathrm{MI}-0,5 \mathrm{SDI}$ & Kurang positif \\
\hline 5 & $\bar{x}<\mathrm{MI}-1,5 \mathrm{SDI}$ & Sangat kurang positif \\
\hline
\end{tabular}

(Diadaptasi dari Nurkancana \& Sunartana, 1992) 
Rumusan untuk MI dan SDI adalah:

MI $=1 / 2($ skor tertinggi + skor terendah $)$

$\mathrm{SDI}=1 / 6$ (skor tertinggi - skor terendah)

Kriteria keberhasilan untuk tanggapan anak adalah jika dari analisis diperoleh hasil minimal berkategori positif.

\section{HASIL DAN PEMBAHASAN}

Penelitian ini mengukur peningkatan kemampuan menyimak anak kemudian membandingankan hasil peningkatan antara sebelum dan sesudah diberikannya tindakan. Observasi dilakukan selama pelaksanaan tindakan, dengan melakukan pencatatan, baik menggunakan catatan lapangan (field note), lembar observasi maupun instrumen yang telah disediakan.

Setelah diberikan tindakan berupa bermain peran. Terdapat peningkatan skor kemampuan menyimak dari awal asesmen sampai pada akhir siklus II, dapat dilihat dari tabel berikut.

\section{Perbandingan Skor Kemampuan Menyimak Pra Tindakan,}

Siklus I dan Siklus II

\begin{tabular}{|c|c|c|c|c|c|c|c|c|c|c|c|}
\hline \multirow[b]{2}{*}{ No. } & \multirow{2}{*}{$\begin{array}{c}\text { Aspek } \\
\text { Kemampuan } \\
\text { Menyimak }\end{array}$} & \multicolumn{3}{|c|}{ Asesmen awal } & \multicolumn{3}{|c|}{ Siklus I } & \multicolumn{3}{|c|}{ Siklus II } & \multirow{2}{*}{$\begin{array}{c}\text { Pening } \\
\text { katan }\end{array}$} \\
\hline & & skor & $\begin{array}{l}\text { Rata- } \\
\text { rata }\end{array}$ & $\%$ & skor & $\begin{array}{l}\text { Rata- } \\
\text { rata }\end{array}$ & $\%$ & skor & $\begin{array}{l}\text { Rata- } \\
\text { rata }\end{array}$ & $\%$ & \\
\hline 1 & Kerjasama & 4,62 & 0,77 & 77,01 & 4,86 & 0,81 & 81,03 & 5,86 & 0,98 & 97,6 & 26,73 \\
\hline 2 & Komunikasi & 7,55 & 0,54 & 53,94 & 10,38 & 0,74 & 74,14 & 11,48 & 0,82 & 82,02 & 52,05 \\
\hline 3 & Berbagi & 9,90 & 1,65 & 54,98 & 13,00 & 2,17 & 72,22 & 16,41 & 2,74 & 91,19 & 65,86 \\
\hline 4 & Partisipasi & 9,48 & 1,65 & 54,98 & 13,48 & 2,25 & 74,90 & 16,14 & 2,69 & 89,66 & 63,07 \\
\hline 5 & Adaptasi & 9,41 & 1,57 & 52,30 & 12,83 & 2,14 & 71,26 & 15,03 & 2,51 & 83,52 & 59,69 \\
\hline
\end{tabular}

Dari hasil skor di atas, dapat terlihat peningkatan kemampuan menyimak yang dialami oleh anak setelah diberi tindakan bermain peran. Untuk lebih jelasnya, disajikan peningkatan per aspek kemampuan menyimak.

\section{a. Aspek Kerjasama}

Setelah diberikan tindakan pada siklus II, terjadi kenaikan skor rata-rata sebesar 26,73\% dari skor pra tindakan. Skor Aspek Kerjasama Pra Tindakan, Siklus I, Siklus II. Aspek ini adalah aspek dengan tingkat pencapaian skor yang paling tinggi dibandingkan dengan keempat aspek lainnya. Bahkan beberapa anak telah mencapai nilai penuh sejak tes pra tindakan dan pada dua tes selanjutnya. Seperti yang dapat kita lihat pada histogram di atas pada anak nomor 1, 6, 7 dan 27. Anak nomor 6 dan 27 ternyata adalah anak yang pada hasil kenaikan kelas mendapatkan rangking 2 dan 1. Sehingga pencapaiannya dalam hasil tes ini dapat menunjukkan bahwa tingkat kemampuan kognitif mempengaruhi secara positif hasil tes. Adapun anak nomor 1 dan 6 merupakan anak yang berada di 10 besar kelas. Selain itu mereka juga menyenangi dan mengaku tertarik pada kegiatan yang bersifat komunikatif. Hal ini menjadi modal bagi mereka untuk dapat meningkatkan kemampuan menyimak terutama melalui aspek kerjasama.

\section{b. Aspek Komunikasi}

Berangkat dari pra tindakan sampai pada akhir siklus ke II, skor rata-rata anak dalam aspek komunikasi meningkat hingga mencapai nilai $82,02 \%$ dengan peningkatan sebesar 52,05\%. Berdasarkan hasil analisis data dapat terlihat perkembangan skor anak. Anak nomor 11 dan 16 mendapat nilai yang kurang baik. Dalam keadaan ini anak nomor 11 dapat dikatakan mendapat nilai yang kurang baik pada beberapa aspek. Jika dilihat dari pencapaiannya dalam pelajaran di sekolah, 
ia adalah anak yang termasuk dibawah rata-rata anak lain. Sedangkan anak lain menunjukkan peningkatan sejak dari pra tindakan sampai pada akhir siklus II.

\section{c. Aspek Berbagi}

Hasil skor aspek berbagi pada anak selama pra tindakan sampai siklus II dapat kita lihat pada tabel diatas. Skor Berbagi Pra Tindakan, Siklus I, Siklus II. Dari hasil analisis data dapat terlihat perkembangan skor anak dalam aspek berbagi. Terlihat beberapa anak telah mencapai nilai penuh pada tes siklus II. Terlihat anak nomor 6 dan 13 dapat mencapai nilai penuh sejak siklus I dan mencapainya lagi pada siklus II.

d. Aspek Partisipasi

Skor aspek partisipasi anak mengalami peningkatan sebesar 63,07\% dari tes pra tindakan sampai akhir tes siklus ke II. Adapun perbandingan skor anak dapat dilihat sebagai berikut. Skor Aspek Partisipasi Pra Tindakan, Siklus I dan Siklus II. Berdasarkan hasil analisis data, dapat terlihat peningkatan skor yang terjadi, mulai dari pra tindakan, tindakan siklus I sampai akhir tindakan siklus II. Dapat dilihat dari histogram di atas, anak nomor 3 tidak mengalami perubahan skor. Hal ini mengejutkan karena sebelumnya, akhir siklus I, ia telah diberitahu untuk mengisi jawaban sesuai dengan kemampuannya bukan sesuai dengan jawaban yang telah dia berikan sebelumnya. Namun ternyata ia mengulanginya lagi di tes siklus II. Namun setelah ditanyakan secara langsung, ia bisa menunjukkan skor yang baik ketika dilakukan penilaian.

e. Aspek Adaptasi

Perkembangan skor hasil tes dari aspek adaptasi dapat dilihat dari data yang disajikan pada tabel di atas. Skor Aspek Adaptasi Pra Tindakan, Siklus I dan Siklus II. Mencermati data yang disajikan dalam histogram di atas, dapat terlihat perkembangan skor anak dalam aspek adaptasi. Dapat terlihat perkembangan anak yang mendapat skor sama pada tes siklus I maupun siklus II. Seperti anak nomor 1, 2, 3, 24 dan 26.

Berikut ini adalah perbandingan tindakan dan hasil tindakan siklus I dan Siklus II dalam proses kegiatan yang telah dilakukan. Perbandingan Tindakan Siklus I dan Siklus II untuk Proses Pembelajaran Untuk Mengembangkan Kemampuan menyimak adalah sebagai berikut.

\section{Siklus I}

\section{A. Proses Kegiatan}

1) Pembelajaran melalui metode bermain peran mentransformasi pengetahuan dan mengembangkan perasaan mengenai menyimak. Dengan tahapan persiapan, pelaksanaan dan evaluasi

2) Anak terlibat dalam proses pertukaran informasi dan pengalaman dalam sesi bercerita serta dialog.

3) Kegiatan menyimak sedapat mungkin dihubungkan kepada lingkungan keseharian anak.

4) Pembelajaran dengan metode bermain peran meliputi persiapan/latihan, pendalaman cerita dan karakter dan mengevaluasi cerita dan peran yang mereka mainkan.

5) Anak terlibat dalam proses pertukaran informasi dan pengalaman dalam sesi bercerita

\section{B. Hasil Kegiatan}

Anak-anak mulai menampilkan perilaku yang mencerminkan kemampuan menyimak walaupun perilaku tersebut belum konsisten dan belum ditampilkan oleh semua anak. Anak mulai membicarakan berbagai hal dengan menyimak informasi dengan teman-temannya dan beberapa anak mengingatkan anak lain ketika melakukan tindakan yang tidak mau berkomunikasi dengan 
baik. Beberapa perilaku yang tidak terkait dengan kemampuan menyimak seperti mengganggu teman, mengejek, mulai berkurang.

\section{Siklus II}

\section{A. Proses Kegiatan}

1) Pembelajaran dengan metode bermain peran. Dengan perbaikan dari siklus I yaitu, dialog dalam drama yang tidak terlalu panjang, pemilihan pemain peran yang lebih baik, menggunakan kuis di akhir drama untuk membuat anak lebih menyimak drama.

2) Sesi diskusi menggunakan lebih banyak pendekatan berbagi pengalaman dan mengajak anak untuk berpikir sedikit lebih dalam pada materi drama yang dilakukan.

3) Kegiatan menyimak disisipkan dan dipraktekkan dalam berbagai aktifitas anak di dalam kelas maupun di luar kelas.

4) Pembelajaran dengan metode bermain peran meliputi persiapan/latihan, pendalaman cerita dan karakter dan mengevaluasi cerita dan peran yang mereka mainkan. Dengan perbaikan dari siklus I yaitu, dialog dalam drama yang tidak terlalu panjang, pemilihan pemain peran yang lebih baik, menggunakan pertanyaan di akhir drama untuk membuat anak lebih menyimak drama.

5) Sesi bercerita menggunakan lebih banyak pendekatan berbagi pengalaman dan mengajak anak untuk berpikir sedikit lebih dalam pada materi drama yang dilakukan.

\section{B. Hasil Kegiatan}

Sebagian besar anak telah memahami isu-isu lingkungan yang dibahas dan mengetahui apa yang bisa dilakukan untuk membantu mengatasi hal tersebut. Perilaku yang diharapkan telah seringkali muncul pada sebagian besar anak. Semakin banyak anak yang menampilkan perilaku yang mencerminkan kemampuan menyimak seperti kerjasama, komunikasi dan adaptasi. Beberapa anak melakukan dengan lebih baik lagi yaitu dengan mengingatkan teman yang lain.

Berdasarkan hasil penelitian ini, implementasi metode bermain peran untuk peningkatan kemampuan menyimak, merefleksikan hipotesis yang peneliti susun berdasarkan teori-teori tentang bermain peran yang diantaranya dari Bruner menyatakan bahwa bermain peran dapat menjadi sarana pembelajaran yang baik bagi anak usia dini karena telah mengandung unsur waktu berkelompok dan unsur pertunjukkan atau bercerita. Demikian pula pendapat Joice dan Weil bahwa bermain peran merupakan tindakan peragaan untuk pemecahan masalah yang bertujuan untuk 1) mengeksplorasikan perasaan-perasaan, 2) memperoleh pemahaman tentang sikap-sikap, nilai-nilai dan presepsinya, 3) mengembangkan keterampilan dan sikap untuk pemecahan masalah, 4) menelaah pokok masalah, peran, cara pemecahan masalah.

Hasil evaluasi pada proses tindakan, peneliti dan kolaborator telah melaksanakan tindakan pemebelajaran sesuai dengan disain pembelajaran yang telah direncanakan dan disesuaikan sebelumnya. Semua desain terlaksana dengan cukup baik walaupun pada siklus I masih terdapat beberapa kendala diantaranya penyesuaian untuk mengkondisikan anak-anak untuk dapat mengikuti drama dengan baik, serta kemampuan beberapa anak yang dirasa sangat kurang untuk memainkan peran dengan baik. Hal tersebut diatasi di siklus II dengan memilih hanya anak-anak yang dapat menampilkan drama dengan cukup baik saja sehingga cerita drama dapat dengan lancar ditampilkan di depan kelas.

Peneliti dapat melihat proses evaluasi dan diskusi yang dilakukan setelah melakukan drama sangatlah penting dalam menentukan keberhasilan keseluruhan proses pembelajaran dengan metode bermain peran ini. Dalam diskusi inilah anak-anak banyak mengeluarkan pendapat, berbagi pengalaman 
dan menyatukan hati dan pikiran mereka dalam mengahadapi isu-isu yang dibawa dalam drama. Kemampuan pengajar (teaching skill) untuk mengendalikan jalannya proses diskusi dapat membawa hasil yang berbeda dalam keberhasilan proses pembelajaran. Hal ini dialami oleh peneliti sendiri yang menjalani siklus pertama dengan sesi diskusi yang kurang terfokus karena belum dapat dengan baik mengatur anak-anak di kelas III.

Untuk membuktikan keberhasilan target yang dicapai melalui serangkaian tindakan yang dilakukan, selain dari pengamatan, maka wawancara yang dilakukan juga terhadap guru kelas, guru mata pelajaran, guru piket dan anak-anak yang menjadi subjek penelitian. Hasil wawancara dengan guru mengatakan banyak perubahan positif yang terlihat dari anak-anak kelompok A yang menjadi subjek penelitian. Adapun hasil wawancara dengan anak-anak yang dijadikan subjek penelitian, ratarata mengaku senang dengan metode bermain peran. Mereka juga menjadi lebih menjaga komunikasi dengan teman. Ada juga yang mengaku tambah rajin dan senang berkomunikasi.

Berdasarkan uraian yang telah dikemukakan diatas, dapat dinyatakan bahwa kegiatan bermain peran cukup efektif dalam meningkatkan kemampuan menyimak. Walaupun ada sedikit hambatan, namun menjadi bahan evaluasi untuk meningkatkan performa metode ini. Dalam wawancara dengan guru kolaborator, guru merasakan metode ini dapat menjadi alternatif untuk digunakan secara lebih terstruktur dalam rencana pembelajaran. Namun selain itu, guru juga merasa metode ini membutuhkan persiapan yang tidak sederhana sebelum diterapkan di kelas. Selain itu, hambatan yang sering terjadi adalah dalam proses diskusi, guru harus pandai-pandai mengarahkan dan memfokuskan jalannya diskusi sambil tetap mendorong anak untuk berekspresi dan berbagi dengan grup diskusi, sehingga tujuan dari pembelajaran dengan metode bermain peran dapat tercapai dengan baik.

Namun demikian, terdapat keterbatasan yang didapati dalam penelitian ini, yang sedikit banyak mempengaruhi tingkat efektifitas penerapan metode ini, yaitu keterbatasan waktu pertemuan. Waktu pertemuan dibatasi oleh jadwal pelajaran lain. Biasanya pertemuan berlangsung selama 2 jam pelajaran. Namun beberapa kali, hanya tersedia waktu 1 jam pelajaran. Hal ini disebabkan jadwal atau kegiatan akademik lain seperti ulangan. Hal ini kadang membuat pertemuan menjadi kurang maksimal. Seperti ketika diskusi masih belum optimal, pertemuan sudah harus dihentikan.

\section{PENUTUP}

Penelitian ini mengkaji tentang implementasi metode bermain peran dalam upaya meningkatkan kemampuan menyimak anak kelompok A di PAUD Sekarwangi Desa Bangorejo Banyuwangi. Berdasarkan hasil analisis data dan pembahasan, dapat diambil kesimpulan sebagai berikut: 1) Terjadi peningkatan kemampuan menyimak anak setelah diberikan pembelajaran dengan metode bermain peran. Hal ini dapat dilihat dari hasil observasi dan hasil test anak secara keseluruhan pada siklus I dan siklus II. Peningkatan kemampuan menyimak terjadi pada kelima aspek yang diteliti, Terjadi peningkatan kemampuan menyimak anak setelah diberikan pembelajaran dengan metode bermain peran. Hal ini dapat dilihat dari hasil observasi dan hasil test anak secara keseluruhan pada siklus I dan siklus II. Tiga aspek yang dijadikan fokus pengembangan pada kemampuan menyimak, yaitu aspek kemampuan kerjasama, komunikasi, berbagi, partisipasi, dan adaptasi meningkat. Metode bermain peran yang dilakukan adalah metode bermain peran yang terdiri dari persiapan (memilih pemain, menyiapkan pengamat, menjelaskan cerita), pelaksanaan bermain peran, evaluasi dan diskusi.

Berdasarkan kesimpulan dan implikasi penelitian tersebut di atas, ada beberapa saran yang dapat disampaikan sebagai berikut: 1) Peneliti berharap guru mau terus menggali dan mengembangkan potensi yang dimiliki setiap siswa dengan menerapkan metode-metode yang menyenangkan, inovatif, dan kreatif. Salah satunya dengan menerapkan bermain peran sebagai menu pembelajaran sekolah. 2) Kepada kepala sekolah untuk dapat memberikan pembinaan, arahan, dan motivasi kepada guru agar 
mau menjadi guru yang berdedikasi tinggi dan memantau kegiatan pembelajaran, baik di dalam kelas maupun di luar kelas, terutama dalam penekanan "belajar sambil bermain". 3) Kepada orang tua untuk dapat memberikan perhatian yang cukup, bimbingan, dan mau bekerjasama dengan guru dalam kegiatan pembinaan anak, karena tanpa kerjasama maka sulit mencari jalan keluar bagi permasalah yang dihadapi putra-putri kita.

\section{DAFTAR PUSTAKA}

Afifaturahmah, Yuni. Peningkatan Kemampuan Menyimak Melalui Metode Cerita Pendek di TK Blitar. Skripsi, 2007.

Blatner Adam M.D, Role Playing Education, First written in 1995, and corrected October 18, 2009.

Bredekamp Sue, Effective Practices in Early Childhood Education: Building a Foundation, New York: Merril, 2010

Brewer, Jo Ann. Introduction to Early Childhood Education, Preschool Through Primary Grades, Sixth Edition. America: Pearson Education, 2007.

Departemen Pendidikan dan Kebudayaan, Program Kegiatan Belajar Taman Kanak-kanak, Pedoman Kegiatan Belajar Mengajar. Jakarta: Depdikbud, 1995.

Didaktik Metodik Umum di Taman Kanak-kanak. Jakarta: Erlangga, 1999.

Djojosuroto, Kinayati \& M.L.A Sumaryati, Prinsip-prinsip Dasar Penelitian Bahasa dan Sastra. Bandung : Nuansa, 2010.

Hardidjoyopuro, Siswono. Action Reseach. Jakarta: IKIP Jakarta, 1997.

Jamaris, Martini. Perkembangan dan Pengembangan Anak Usia Taman Kanak- kanak. Jakarta: Grasindo, 2006.

Kamidjan dan Suyono. Menyimak. Direktorat SLTP. Jakarta: Ditjen Dikdasmen, 2001.

Kurikulum 2004, Standar Kompetensi Pendidikan Anak Usia Dini; Taman Kanak-kanak dan Raudhatul Athfal, Jakarta: Departemen Pendidikan Nasional, 2003.

Masito, dkk. Metode Pengembangan Bahasa. Jakarta:Pusat Pembinaan Bahasa. 2005. 